\|III!I総＼cjkstart説

\title{
中高年者の糖代謝機能に及ぼす運動の効果
}

\author{
佐 藤 祐 造 \\ 名古屋大学総合保健体育科学センター
}

Effects of Physical Exercise Training on the Carbohydrate Metabolism

in Middle Aged and Aged Subjects

Yuzo Sato

Research Center of Health, Physical Fitness and Sports, Nagoya University

はじめに

加齢に伴い糖・脂質代謝機能が低下し, 糖尿病, 高血圧症, 高脂血症及び脳卒中, 心筋梗塞など動脈硬化性 疾患に罹患する頻度が増大することはよく知られた事実である。近年における食生活の洋式化と, 職場や家庭 におけるオートメーション（OA）化は，このような傾向を更に增加させている。

一方, 食生活の是正と身体トレーニングの実施など, ライフスタイルの改善は, これら加龄に伴う糖・脂質 代謝異常や動脈硬化性疾患の発現を防止したり, 遅延させる効果がある ${ }^{1,2)}$ 。

しかしながら, 高齢者の運動機能は低下しており, その特徽は以下の如くまとめることができる。(1) 体 力・生理的予備力の低下, (2) 個人差の増大, (3) 臓器・組織の脆弱化 (骨粗漀症の出現), (4) 回復の遅延, (5) 血圧の立進, (6) 最高心拍数の低下, (7) 運動許容量の幅が少ない11。

従って, 高齢者に運動を指導する際には, このような身体特性を十分理解した上で各人個別の運動処方を作 成し、“テーラーメイド”に実施しなければならない。

本稿では, 加齢に伴う糖代謝異常に及ほす身体トレーニングの影響及びトレーニング方法の実際について概 説したい。

\section{I. 高齢者にみられる糖代謝異常の特徵}

\section{1. 耐糖能異常}

高齢者の代謝機能の特徵は，加齢に必然的に付随する生理的な変化と病的状態とが区別しにくい点にある。 すなわち, 高齢者では糖の処理能力が低下し，糖尿病またはそれに近い状態になることが多い。しかし，高齢 期になっても，糖代謝が全く正常な場合もあり，軽度の糖代謝の低下を加齢に伴う生理的な変化と断定するこ とはできない尚)。

筆者ら ${ }^{4)}$ は，かつて老年ラットの糖代謝に関わる肝解糖系酵素活性の変動に検討を加えた（図 1 )。72時間 絶食により，低下した䤉素活性は再椇食により回復するが，老年ラットでは若年ラットに比べて回復速度が遅 い。しかし，一定時間経過後にはほほ同程度まで回復した。すなわち，老年ラットの肝糖処理能力は，質的， 量的に若年ラットとほとんど同程度であるが，時間的な適応能力は著しく低下していた。従って，少なくとも 肝解糖系酵素活性の動態に関する限り，時間的要因を無視すれば回復しうる点から，糖尿病とは根本的に病因 を異にすることとなる。言い換えれば，高齢者の糖代謝能は環境条件が一定範囲内に限定されているsteady stateでは若年者と同等に保持されているが，環境が急激に変化するemergency の場合には恒常性を維持する 

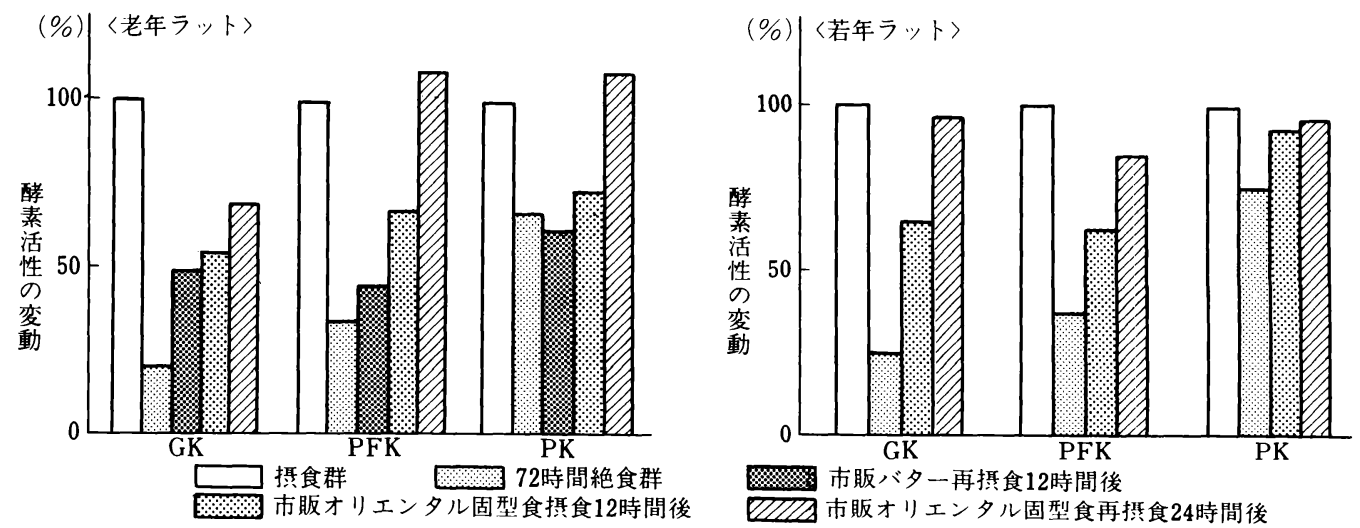

困 1 ラット肝解糖系律速酵素活性の変動 (72時間絶食後の回復過程における老年・若年ラットの相違)

注) GK : glucokinase, PFK : phosphofructokinase, PK : pyruvate kinase

能力が容易に破綻し, 一過性にでも糖尿病 状態が出現すると結論される。

\section{2. 糖代謝異常の成因}

高齢者にみられる糖尿病状態には, 老化 に伴う膵ラ氏島, 末梢組織など各臟器, 組 織の機能低下の総合的表現として出現する 場合と, 肥満, 脳血管障害, 虚血性心筋障 害など高齢者に好発する疾患, あるいはそ れに対する治療に伴って 2 次的に発現する 場合が考えられる3,4)（表 1）。
表 1 高齢者糖尿病状態の病因

1. 加龄による膵島機能の隇退・末梢組織糖利用能の減退

2. 高齢者に好発する疾患に基づく糖尿病状態
1) 肥満
2）脳血管障害
3）虚血性心筋障害
4) 肝硬変
5）膵疾患

3. 高齢者に好発する疾患の治療に基づく糖尿病状態

1）高血圧症（降圧利尿薬）

2) 膵癌 (猝摘出)

3）リウマチ性疾患（ステロイド）

Davidson ${ }^{3}$ は, 加齢に伴う耐糖能障害の成因として, (1) 食事攝取不良, (2) 不活動性, (3) 除脂肪体重 lean body mass (LBM)の減少, (4) インスリン分泌の低下, (5) insulin antagonist（インスリン抵抗性）などの可能 性を指摘した。この中で, 高齢者にみられる食事摄取の不良と不活動性は, 高齢者における耐糖能障害の一部 の成因となりうるが，全てを説明するには至らない。負荷した糖質を 1 次的に貯える筋肉など，LBMの減少 も高齢者にみられる耐糖能障害の主因となり得ない。高齢者では，グルコースに対するインスリン分泌が正常 または過剩反応を呈する場合が多く，耐糖能障害がインスリン反応の低下に起因する可能性は少ない。従って， 現時点では，高齢者にみられる耐糖能障害の原因としては，insulin antagonistの存在が想定される。

DeFronzo $0^{5)}$ は，glucose（またはinsulin）clamp法を用いて，高龄者の末梢組織におけるインスリン感受性と グルコースに対する膵 $\beta$ 細胞の反応性とについて検索を加えた。血糖値を空腹時レベルに維持する euglycemic clamp法では, 高齢者のグルコース代謝量（M）は若年者より有意に低下しており $(p<0.001)$, 高齢者では 外因性インスリンに対する感受性が低下していることがうかがわれた。次に，グルコース注入量を調節するこ とにより, 空腹時より $125 \mathrm{mg} / \mathrm{dl}$ 高いレベルの血糖値を維持したhyperglycemic clamp法を実施したが, 高齢者 のM值は若年者より有意に低下しており $(p<0.001), \mathrm{M}$ 值と年齢との間には負の相関関係が認められた $(r=$ $-0.665, p<0.001$; 図 2$)$ 。以上の成績から, DeFronzoは高龄者にみられる耐糖能障害は, 末梢組織のイン スリンに対する感受性低下に起因すると結論づけている。 
筆者ら ${ }^{6}$ も，加齢と体の非活動性がインスリン感受 性に及ほす影響について検討を加えた。高齢者に $75 \mathrm{~g}$ 糖負荷試験を行い，若年対照群の成績と比較した（図 3 )。その結果, 加齢そのものによる耐糖能及び末梢 インスリン感受性の低下は, ほとんど問題にならない が, それに身体的非活動性が併存する場合は，インス リン分泌低下を伴う耐糖能異常と著明なインスリン感 受性の低下が認められ，糖代謝に重大な影響を与える ものと考えられた。

\section{II. 高齢者の糖代謝異常と身体運動の実施} 効果

\section{1. 安静の奖害}

糖尿病, 肥満がいわゆる肉体労働を職業としている

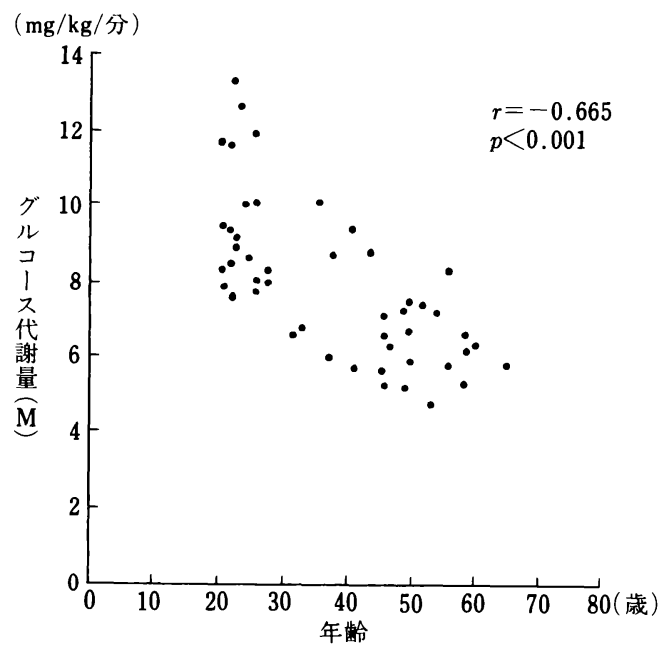

図 2 加秢と hyperglycemic insulin clamp 法による組 織のグルコース代謝量 $(\mathrm{M})$ との相関関係 ${ }^{5)}$

人に少なく，軽労働，管理業務を行っている人に多いことはよく知られている7)。

運動不足（身体的不活動性）は，筋を中心とした末梢組織におけるインスリン作用を低下させ（インスリン 抵抗性), 糖代謝に異常を来すこととなる ${ }^{6)}$ 。すなわち, 近年における家庭, 職場におけるオートメーション 化, コンピュータ化などいわゆる文明化された日常生活は, 洋式化された食生活, グルメ志向と相まって, 運 動不足と過食から糖尿病, 肥満を代表例とするいわゆる “運動不足病” (hypokinetic disease) を増加させてい る7。このような病態は, “X 症候群” (syndrome X ; Reaven, 1988年), “死の四重奏” (deadly quartet ; Kaplan, 1989年), “インスリン抵抗性症候群” (syndrome of insulin resistance；DeFronzo, 1991年) と研究者,
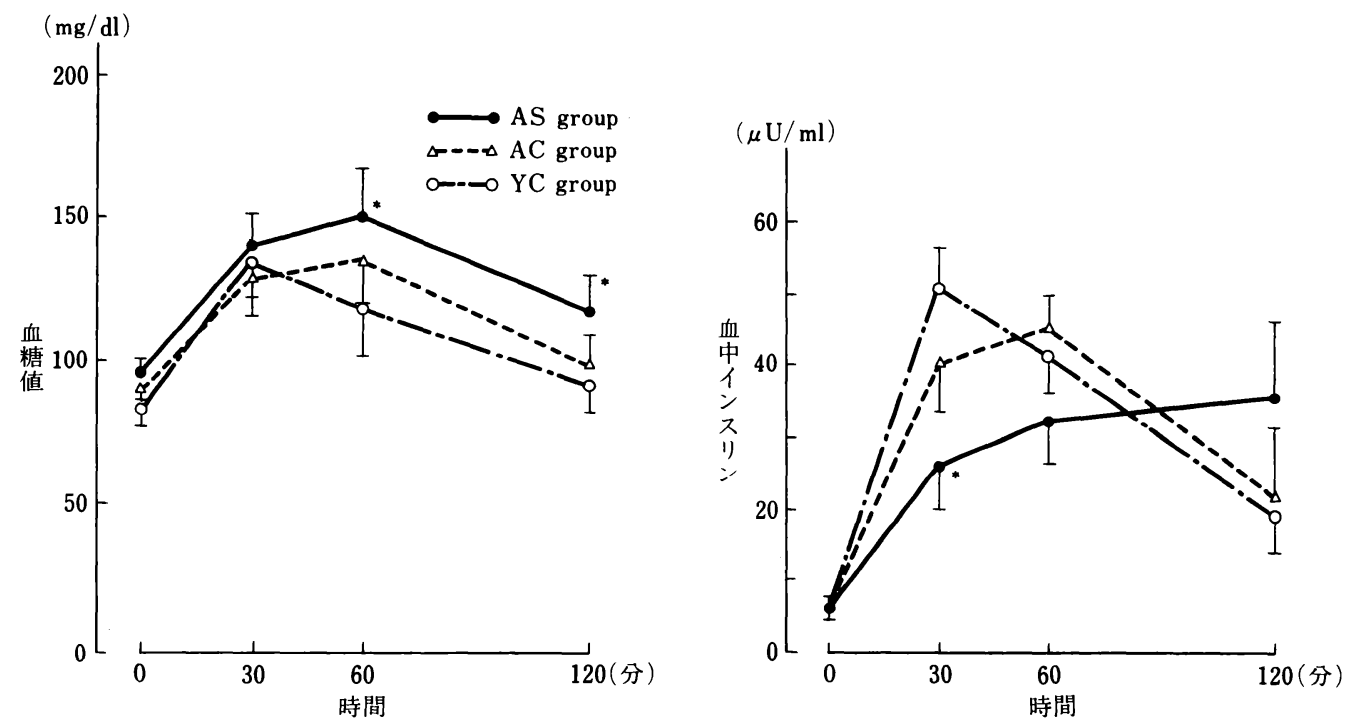

図 $375 \mathrm{~g}$ 糖負荷試験における血糖值と血中インスリン

注） AS：高舲寝たきり群, AC：高秢对照群, YC：若年対照群 ${ }^{*} \mathrm{YC}$ との間に有意差あり $(p<0.05)$ 


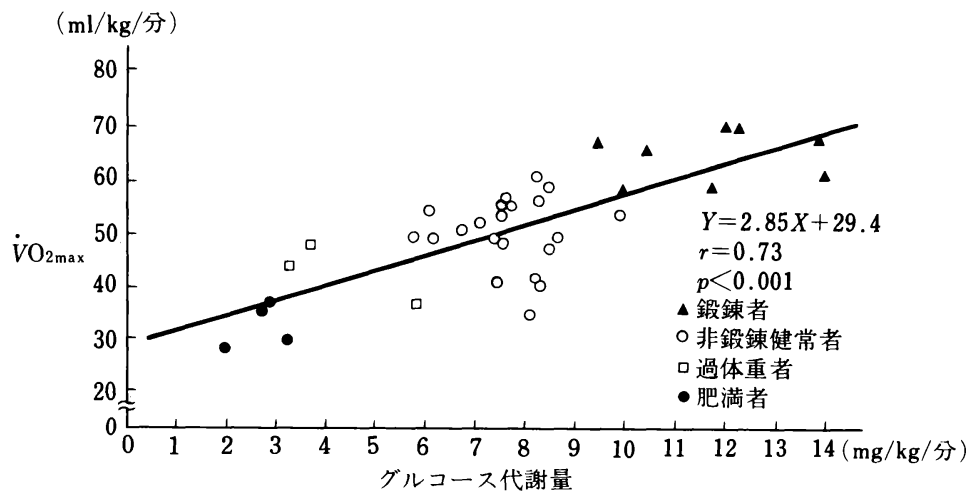

図 $4 \dot{V} \mathrm{O}_{2 \max }$ とグルコース代謝量との相関

臨床家の間で注目を集めている

このように，インスリン感受性（抵抗性）低下の状態とそれに伴う代償性の高インスリン血症が, 糖尿病だ けでなく, 高血圧, 高脂血症, 動脈硬化性心臓病など多くの成人病の発症や進展に関与していることが判明し ている。

身体トレーニングの継続は，個体のインスリン感受性を改善させるが，単に糖尿病，肥満の病態改善に良好 な影響をもたらすだけでなく，加齢に伴うインスリン作用低下，高血圧，高脂血症，動脈硬化性心臓病などイ ンスリン抵抗性関連の全ての病態の改善に有用である ${ }^{7 \sim 10)}$ 。

\section{2. 運動の短期効果}

運動を行えば，運動（収縮）筋でグルコースや脂質の利用が促進され，肥满の防止，改善効果がある。

中等度以下の運動では, 糖質と脂質の両者がエネルギー源として利用される比率が増大し, 乳酸性閾值 （lactate threshold；LT）を超え，血中に乳酸が蓄積すれば，血中遊離脂肪酸（FFA）濃度は次第に低下する (現象論的には脂肪分解が低下する)。また，強度の強い運動では，動脈硬化の促進因子である血中過酸化脂質 が増加したり ${ }^{11)}$ ，グルカゴン，カテコラミンなど血糖上昇作用のあるインスリン拮抗ホルモン分泌も増大する。 一方, 運動の持続時間との関連から，運動の持続時間が長くなるに従い脂質の利用される比率が増大する。更 に,トレーニングの継続に伴い筋のエネルギー源が次第に脂質に依存することとなる（ $\beta$ 酸化の活性化による 筋グリコーゲンの節約 $)^{9)}$ 。

従って,インスリン作用の活性化を目指した高齢者の運動療法としては, 軽・中等度の全身運動を 1 回に10 〜30分程度，できるだけ長い期間にわたって実施することが望まれる1)。

3. トレーニング効果

(1) 身体トレーニングとインスリン作用改善

加龄によりインスリン作用が低下し，耐糖能が低下することはこれまでも繰り返し述べたが，これに加えて， 加龄に伴う身体的不活動性が個体のインスリン感受性を低下させる可能性が大きい。一方，身体トレーニング の継続は，筋を中心とした末梢組織のインスリン感受性を回復させうる。

そこで，筆者ら ${ }^{12)} は ，$ 高齢者を運動量に従い，いわゆる安静臥床（寝たきり）群，日常生活を行っている 対照群，毎週 10〜20km走っている䤮錬者群の 3 群に分けmultiple euglycemic clamp法 ${ }^{13)}$ 用いて検討を加えた。 
すでに，筆者ら ${ }^{14)}$ はeuglycemic clamp法を 用いて, グルコース代謝量 (注入量) と $\dot{V} \mathrm{O}_{2 \max }$ との間には正相関が成立し, 本法を 用いてトレーニング効果の生化学的定量が 可能であることを証明している（図 4)。

高齢者では若年者と比べて，インスリン 感受性（regular dose；インスリン受容体 動態を反映）が低下しているが，寝たきり 群では殊に低下している。しかし，トレー ニングにより若年非鍛錬対照群のレベルに まで回復することが判明した（図 5 )。一 方, インスリン反応性（high dose；イン スリン受容体以降の動態を反映）に関して, 若年者では鍛錬者, 非鍛錬者に有意差を認 めないが, 高齢者では運動量に応じて, 般

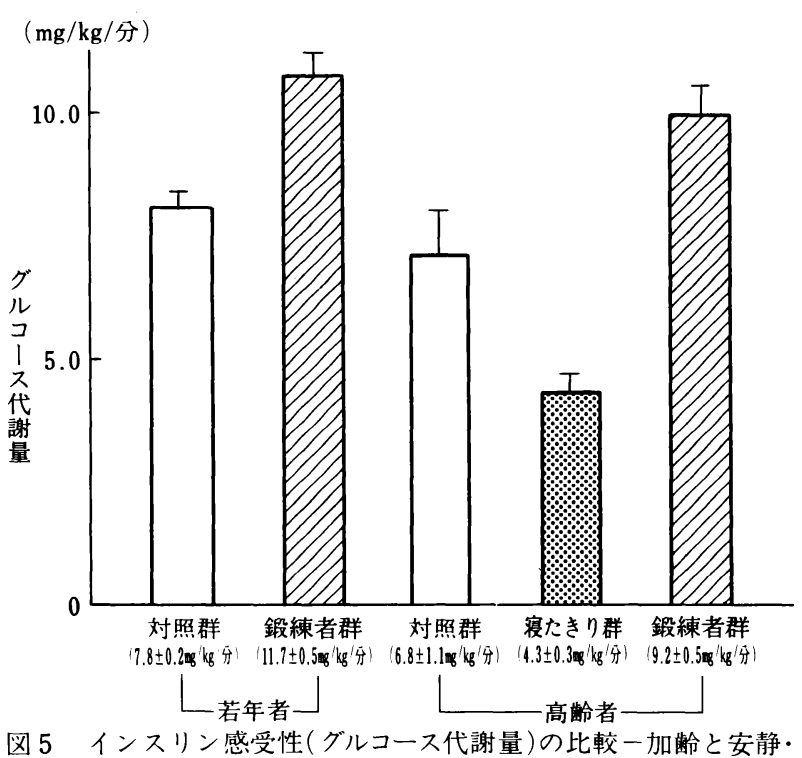
トレーニングによる影響—

錬者群>対照群>寝たきり群となった。

更に，筆者ら ${ }^{15)}$ は，以上に述べた体重換算 M值でけでなく，LBM当たりのM值も算出した。その結果，高 齡者のインスリン感受性（regular dose）に関しては, 鍛錬者群 照群との有意差は消失し，インスリン感受性の増大は筋量の相違による可能性が推察された。一方インスリ ン反応性では, 鍛錬者群>対照群>寝たきり群となった。

従って，高齢者において，身体活動量の低下はLBMばかりか，骨格筋を中心とした末梢組織でのインスリ ン受容体以降のインスリン作用低下を招くことが明らかになった。換言すれば, 高齢者の身体トレーニングの 継続は, LBMやインスリン作用を若年者レベルにまで増大させる可能性を示唆している。また，身体トレー ニングが, 若年者ではインスリン受容体レベルにおいて, 高龄者ではインスリン受容体以降のインスリン作用 を改善させうるともいえる12)。

筆者ら ${ }^{16)}$ は，身体トレーニングの相違が末梢組織におけるインスリン作用に及ぼす影響についても検討を加 えている。その結果, 長距離選手 (LR), 重量挙げ選手（WL）はいずれも個体としては非鍛鍊対照者（HC） と比べてインスリン感受性は増大していた。しかし, LBM 当たりでは, LR $>\mathrm{WL} \fallingdotseq \mathrm{HC}$ なった (図 6$)$ 。こ の事実は，加齡に伴うインスリン作用低下防止のための身体トレーニングには，有酸素運動が無酸素運動より 有用であることを示唆している。

(2) トレーニング効果発現のメカニズム

インスリン感受性の改善を中心とするトレーニング効果の発現には, 筋重量の増大のほか, 骨格筋インスリ ン受容体因子が関与している。また, 箭解糖系 (PFK), TCA回路系 (SDH) 酵素活性や糖輸送担体の変動な ど受容体以降性因子という筋性因子が主体をなしている。しかし，脂肪組織性因子も無視できない9)。

殊に筋糖輸送担体，中でも筋におけるGLUT-4の動態に関しては新しい知見が続々と報告されている ${ }^{17 ~ 19) 。 ~}$ すなわち，筋収縮に際してGLUT-4は細胞内から細胞膜表面へ移動し，糖輸送の増大に対応する。また，卜 レーニングにより筋GLUT-4蛋白量が増大するとともに, 細胞膜部分のGLUT-4の数も増加する。Cartee ${ }^{17)}$ 
よれば, ヒトでは老，若を問わずトレー

ニングはGLUT-4蛋白量を増大させるが, 老ラットでは増大を認めないという。

筆者ら ${ }^{15)}$ もラットに自発運動を行わせ, 身体トレーニングが加齡に伴うインスリ ン作用の低下に及ぼす影響に検討を加え ているので, 簡単に紹介する。

トレーニングを行わない安静ラットで は， 4 週龄に比べて，すでに12週齢でイ ンスリン感受性は有意に低下し，27週齢 では更に低下した。一方，トレーニング を継続したトレーニングラットでは, 12, 27週齢ともインスリン感受性は低下しな かった。また, 成熟後, すなわち，12週
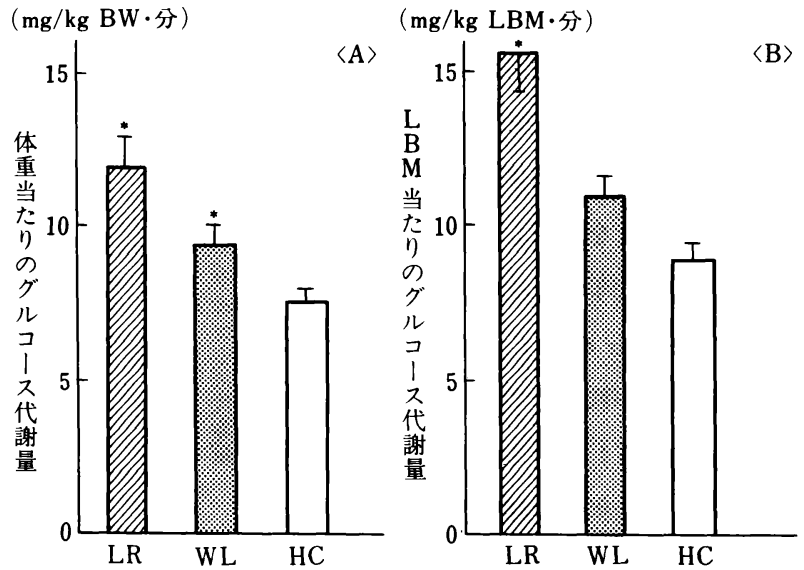

図 6 体重当たり $(\mathrm{A})$ 及び除脂肪体重 (LBM)当たり（B）のグルコ 一ス代謝量(インスリン感受性)

注） LR：長距離選手, WL：重量挙げ選手, HC：非鍛錬对照者。 * $\mathrm{HC}$ との間に有意差あり $(p<0.05)$

齢よりトレーニングを開始したラットでも，27週齢に は成熟前よりトレーニングを実施した群とほぼ同程度 のレベルにまで回復した（図 7 ）。

Western blot法により測定したGLUT-4蛋白量は, トレーニング群で有意に高值であっだ。

以上の事実は, 身体トレーニングは中年以降開始し ても，加齢によるインスリン感受性低下を防止しうる こと, また, このインスリン感受性改善は, 骨格筋細 胞膜上のGLUT-4蛋白の増加に起因していることを示 唆している。

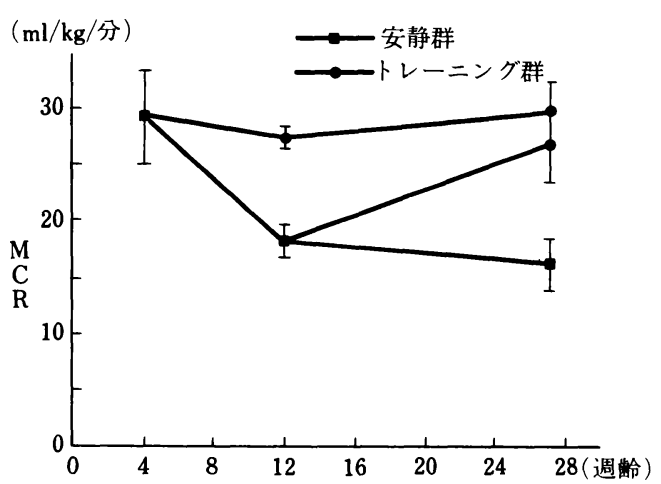

図 7 ラットにおける加䤅に伴うグルコース代謝率 (MCR)の低下に及ぼす身体トレーニングの影響

\section{III. 高齢者にみられる糖代謝異常の対策}

高齢者にみられる糖代謝異常の大部分は, 食事, 運動療法の実施により回復させうるが, 急激な環境の変化 に適応できないという特徽がある。従って, 食生活, 運動を含む日常生活全般についても, 急激な変化を求め る指導を行ってはならない。また，高齢者の尊厳を損なわないよう配慮する。

食事に関しては，大量の糖質の負荷は望ましくなく，食事はできるだけ頻回に分け（4〜6回）, 少量ずつ 撕取するよう勧める。

運動も過激な運動を避け，軽い運動から徐々にマイペースで強い身体トレーニングを実施するよう指導する。

具体的には, $\dot{V} \mathrm{O}_{2 \max } 50 \%$ 前後（60〜 70歳で脈拍 110/分程度）の中等度運動を 1 回10〜30分, 週に 3 日以上 行わせるよう指導する。運動の種類としては, 散歩, 速歩, 水泳, 自転車, ラジオ体操など全身を使った動的 運動が勧められる。歩数計, カロリーカウンター®は運動量の把握に有用である ${ }^{20)}$ 。最近の筆者ら ${ }^{21)}$ の臨床成 績によれば，個体のインスリン感受性の改善 ( $\triangle \mathrm{MCR})$ と歩数計の歩数とは正の相関関係が存続することが判 明している。 
運動実施の効果は, 単に糖代謝の改善にとどまらず, 脂質代謝 ${ }^{22)}$ や動脈硬化性血管障害の子防, 体力の保持 增進, 骨粗䉘症や老人性痴呆症にも有効である ${ }^{9)}$ 。

\section{おわりに}

運動実践が高齢者にみられる糖代謝異常に及ほす影響について, 従来, 医学, 殊に臨床医学の面から検討が 加えられることが少なかった身体トレーニング効果の内分泌代謝学的側面に重点を置き, 概説した。高齢社会 を迎え，この方面の研究のなお一層の進展とそれを基盤とするよりよい高齢者対策の実施が期待される。

本論文の要旨は, 第 1 回運動・栄養と老化に関する国際セミナー (1994年11月, 於国立健康・栄養研究所) で講演された。なお, 自験成績の一部は, 厚生省シルバーサイエンス研究 (小林班), 長寿科学総合研究 (板 倉班，佐藤班）の援助によった。

\section{文献}

1）佐藤祐造：高齢者の健康管理と健康增進, 長寿を考える/名古屋大学公開講座委員会編, pp. 176 186 (1993) 第一法規, 東京

2) Sato, Y. et al. : Improved insulin sensitivity and responsiveness after long-term physical training in aged subjects, In Insulin Resistance in Human Disease/Huh, K. B. et al., eds., pp. 249 252 (1993) Elsevier Sci Pub, Amsterdam

3) Davidson, M. B. : The effect of aging on carbohydrate metabolism, Metabolism, 28, 688 705 (1979)

4）坂本信夫，佐藤祐造：高齢者の糖代謝の特徵と管理，JJPEN, 13，923９26（1991）

5) DeFronzo, R. A. : Glucose intolerance and aging: Evidence for tissue insensitivity to insulin, Diabetes, 28, 1095 1101 (1979)

6）佐藤祐造，他：加歯に伴う身体的非活動性の耐糖能及びインスリン感受性に及ほす影響，日本老年医誌, 27, 564 569 (1990)

7）佐藤祐造：成人病の予防と運動一糖尿病・肥満を中心として一, 明日の臨床，6, 1 11 (1994)

8) DeFronzo, R. A. et al. : Insulin resistance: A multifaceted syndrome responsible for NIDDM, obesity, hypertension, dyslipidemia and atherosclerotic cardiovascular disease, Diabetes Care, 14, 173 194 (1991)

9）佐藤祐造：糖尿病と運動，体力科学， 42，101 110（1993）

10）佐藤祐造：老年者・肥渵者の運動, 糖尿病学の進歩' 93 , 第 27 集/日本糖尿病学会編, pp.132 136 (1993) 診断と治療社, 東京

11) Yagi, K. : Lipid peroxides and exercise, In Integration of Medical and Sports Sciences/Sato, Y. et al., eds., pp. 40 42 (1992) Karger, Basel

12) Yamanouchi, K. et al. : Effect of daily physical activity on insulin action in the elderly, J. Appl. Physiol., 73, 2241 2245 (1992)

13) King, D. S. et al. : Effect of exercise and lack of exercise on insulin sensitivity and responsiveness, $J$. Appl. Physiol., 64, 1942 1946 (1988)

14) Sato, Y. et al. : Biochemical determination of training effects using insulin clamp and microdialysis techniques, In Integration of Medical and Sports Sciences/Sato, Y. et al., eds, pp. 193 200 (1992) Karger, Basel

15) Sato, Y. et al. : Effect of physical training on the decreased insulin action caused by diabetes, obesity and aging. Presented at the symposium "Exercise stress responses in muscle" in 2nd International Congress 
of Pathophysiology, Kyoto (1994)

16）押田芳治，他：身体トレーニングの相違が末梢組織におけるinsulin actionにおよぼす影響について 一Euglycemic clamp法を用いての検討一, 体力科学, 40, 315 320（1991）

17) Cartee, G. D. : Influence of age on skeletal muscle glucose transport and glycogen metabolism, Med. Sci. Sports Exer., 26, $577 \sim 585$ (1994)

18) Hall, J. L. et al. : Exercise does not compensate for age-related decrease in myocardial GLUT-4 content, $J$. Appl. Physiol, 76, 328 332 (1994)

19）佐藤祐造：Annual Review内分泌, 代謝1994, pp. 124 128 (1994) 中外医学社, 東京

20）佐藤祐造：糖尿病運動療法指導の手びき（1991）南江堂, 東京

21) Yamanouchi, K. : Daily walking combined with diet therapy is a useful means for obese NIDDM patients not only to reduce body weight but also to improve insulin sensitivity, Diabetes Care, 18, $775 \sim 778$ (1995)

22) Higuchi, M. et al. : Effects of exercise on plasma lipid metabolism and exercise therapy of hyperlipidemia, Med. Exer. Nutr. Health, 3, 308 316 (1994) 